\title{
Evaluating antioxidant potential, cytotoxicity and intestinal absorption of flavonoids extracted from medicinal plants.
}

\author{
Sharma R.J. *, Chaphalkar S.R. and Adsool A.D. \\ *VidyaPratishthan's, Arts, Science and Commerce College Vidyanagari, Baramati, 413 133, Pune \\ raajesh_sharma2004@yahoo.com
}

\begin{abstract}
Plants described in Ayurvedic literature namely, A. catechu, E. officinalis, F. benghalensis, $F$. glomerata, and $T$. arjuna possess significant amount of flavonoids as secondary metabolites. These compounds are reported to exhibit various biological activities, including antioxidative and free radical scavenging activities. Antioxidant compounds in food play an important role as a health-protecting factor. Scientific evidence suggests that antioxidants reduce the risk for chronic diseases including cancer and heart disease. The flavonoids extracted from bark of these plants were fractionated using HPTLC. These were assessed for the antioxidant potential employing DPPH [1, 1- Diphenyl- 2- picrylhydrazyl] assay. Simultaneously the flavonoids showing comparatively better activity were tested for their Cytotoxicity using MTT [Mitochondrial toxicity test]. The preparation was also subjected for absorption studies in goat intestinal model system.
\end{abstract}

Keywords- Flavonoids, DPPH assay, MTT assay

\section{Introduction}

In living organisms the reactive oxygen species (ROS) and reactive nitrogen species (RNS) are known to cause damage to lipids, proteins, enzymes, and nucleic acids leading to cell or tissue injury implicated in the processes of aging as well as in wide range of degenerative diseases including inflammation, cancer, atherosclerosis, diabetes, liver injury, alzheimer, Parkinson, and coronary heart pathologies, among others. The ROS and the RNS include diverse reactive entities namely superoxide $\left(\mathrm{O}^{-}\right)$, hydroxyl $(\mathrm{OH} \bullet)$, peroxyl $(\mathrm{ROO} \bullet)$, peroxinitrite (•ONOO-), and nitric oxide (NO) radicals, as well as non free radicals species as hydrogen peroxide (H2O2), nitrous acid (HNO2), and hypochlorous acid ( $\mathrm{HOCl})$.On the other hand, the aerobic organisms developed antioxidant defense mechanisms that arrest the damage caused by ROS and RNS entities. The defense mechanisms can be enzymatic and nonenzymatic. In the enzymatic mechanisms are included, for instance, superoxide dismutase, catalase, glutathione reductase and peroxidase, and nitric oxide synthase enzymes, among others. On the contrary, in the non-enzymatic mechanisms are comprised antioxidants and trapping agents such as ascorbic acid, $\alpha$ tocopherol, $\beta$-carotene, glutathione, flavonoids, uric acid, cysteine, vitamin $\mathrm{K}$, serum albumin, bilirubin, and trace elements as zinc and selenium, among others. Both processes can contribute to prevent the damage caused by oxidative reactions. Since the natural antioxidant mechanism in mammalians under some circumstances can be inefficient, a dietary intake of antioxidant compounds becomes an alternative, once it has been suggested that there is an inverse relationship between dietary intake of antioxidants and the incidence of diseases caused by the deficiency on these substances. In recent years, synthetic antioxidants such as

buthylated hydroxyanisole (BHA) and buthylated hydroxytoluene (BHT) are added to food preparations because they are good free radical scavengers, even though there are some experimental evidences that they induce DNA damage. Therefore, there is an increasing interest in searching antioxidants from natural origin to scavenge free radicals to prevent human body from oxidative stress produced by ROS and RNS species. According to Hostettmann and Terreaux (2000), the estimated number of higher plant species in the world is of 400,000 , the fact that plant secondary metabolites are characterized by an enormous chemical diversity and that currently one-fourth of all prescribed pharmaceuticals compounds in developed countries are directly or indirectly (semi-synthetic) derived from plants. As plants produce a huge amount of antioxidants they can represent a source of new compounds with antioxidant activities. Flavonoids are a group of polyphenolic compounds, which have the diphenylpropane (C6-C3-C6) skeleton, ubiquitously found in fruits and vegetables. The flavonoid family includes flavones, flavonols, flavanones, flavanonols, flavans, flavanols, leucoanthocyanidins, anthocyanidins, aurones, chalcones, and isofavones. The structural difference in each flavonoid family results from the variation in the number and arrangement of the hydroxyl groups and the extent of glycosylation. Epidemiological studies suggest that the consumption of flavonoids is effective in lowering the risk of coronary heart disease. In addition, the flavonoids exhibit a wide range of biological activities, including anticarcinogenic, antiinflammatory, antiradical, and antioxidant actions. Especially, they may exert antioxidative effects as free radical scavengers, hydrogendonating compounds, singlet oxygen quenchers, 
and metal ion chelators, properties attributed to the phenolic hydroxyl groups attached to the ring structures. From this point of view, the main goal of this research was to study the plants namely Acacia catechu, Emblica officinalis, Ficus benghalensis, Ficus glomerata, and Terminalia arjuna [Sanskrit names Khair, Amla, Nyagrodha, Udumbara, and Arjun respectively] reportedly containing good quantity of flavonoids, extract the flavonoids, quantify them by using spectrophotometer and assess their antioxidative property using DPPH [1, 1- Diphenyl- 2picrylhydrazyl], at the same time check their Cytotoxicity and intestinal absorption using goat model system.

\section{Material and Method}

Flavonoids; Quercitin [Fluka, Switzerland 60260 58K] Rutin [Kindly provided by Anchrom laboratory, Mulund (E), Mumbai] Methanol, Ethyl acetate, Formic acid, [Qualigen Chemicals ]. DPPH [1, 1- Diphenyl- 2- picrylhydrazyl] from [Aldrich Chemicals, US], reading were taken on double beam UV - Visible spectrophotometer [make Jasco - 530] HPTLC silica gel 60 F254 plates [Merck] Sample application by using Linomat 5, Development of plates Twin trough chamber and densitometeric scanning using Scanner 3 [All HPTLC accessories CAMAG made], Fast Blue $B$ salt $\left[3,3{ }^{\prime}\right.$ dimethoxybiphenyl-4, 4'- bis (diazonium) dichloride] for derivation of HPTLC plates. MTT [SRL], 96 well cell culture flat bottom plates with lid [Corning Incorporated 3569, corning, NY14831 US]. The plant material was collected from the Nakshatra Udyan, Vidyanagari, MIDC Baramati. The plants were authenticated by the Botany department of VPASC College, Baramati. The voucher specimen of the plant material has been preserved at $-200 \mathrm{C}$ at VSBT, molecular Biology Laboratory. The plant material was shade dried for 8 days and powdered using mortor pestle. The powder was sieved through mesh number 85 as mentioned in Indian Pharmacopoeia. The powder is labeled as crude drug hence forth. It was utilized within 6 months. The age of the mother plant from which the crude drug is extracted should be $41 / 2$ years or more.

\section{Extraction of flavonoids}

One [01] g crude drug is extracted with $10 \mathrm{ml}$ methanol for 5 min on a water bath at $600 \mathrm{C}$ and then filtered. This rapid method extracts both lipophilic and hydrophilic flavonoids.

\section{Enrichment}

A total of $5 \mathrm{ml}$ of methanolic extract is concentrated to about $2 \mathrm{ml} ; 1 \mathrm{ml}$ water and $10 \mathrm{ml}$ ethyl acetate are added and shaken several times. The ethyl acetate fraction is separated and reduced to a volume of $1 \mathrm{ml}$.

\section{Quantification of flavonoids}

The total flavonoid content was determined using a modified Folin - Ciocalteus colorimetric method with Quercitrin as standard.200 $\mu \mathrm{g} / \mathrm{ml}$ of standard Quercitrin working solution was distributed in $0.00 \mathrm{ml}, 0.2 \mathrm{ml}, 0.4 \mathrm{ml}, 0.6 \mathrm{ml}, 0.8 \mathrm{ml}$ and $1 \mathrm{ml}$ in 6 test tubes. The volume was leveled to $1 \mathrm{ml}$ in each tube by introducing $1 \mathrm{ml}, 0.8 \mathrm{ml}, 0.6 \mathrm{ml}$, $0.4 \mathrm{ml}, 0.2 \mathrm{ml}$ and $0.00 \mathrm{ml}$ in each tube of phosphate buffer $[\mathrm{pH}$ 7.00] giving a final concentration of $00 \mu \mathrm{g} / \mathrm{ml}, 40 \mu \mathrm{g} / \mathrm{ml}, 80 \mu \mathrm{g} / \mathrm{ml}$, $120 \mu \mathrm{g} / \mathrm{ml}, 160 \mu \mathrm{g} / \mathrm{ml}$ and $200 \mu \mathrm{gml}$ respectively. $100 \mu \mathrm{l}$ of ethyl acetate fraction of all five samples was diluted with $900 \mu \mathrm{l}$ phosphate buffer. $3 \mathrm{ml}$ of $1 \mathrm{~N}$ Folin - Ciocalteus reagent was added to each of the tubes followed by addition of $4 \mathrm{ml}$ sodium carbonate [7.5\%]. The tubes were incubated at room temperature for $45 \mathrm{~min}$ in dark. Absorbance was recorded at $765 \mathrm{~nm}$, using double beam Jasco- 530 UV- Visible Spectrophotometer. The readings were taken in duplicates and mean values were plotted.

\section{HPTLC}

$20 \times 10$ HPTLC silica gel 60 F254 plates were used. The plates were pre run with methanol till $90 \mathrm{~mm}$ in twin trough chambers saturated with methanol. $5 \mu \mathrm{l}$ and $10 \mu \mathrm{l}$ sample were applied using Linomat 5. 14 tracks each of $8 \mathrm{~mm}$ were applied per plate, position of first track was $14 \mathrm{~mm}$ [X axis] and distance between the tracks was $14.7 \mathrm{~mm}$. The mobile phase was Ethyl acetate formic acid - glacial acetic acid - water [10:1.1:1.1:2.6]. The mobile phase or solvent front was allowed to run till $80 \mathrm{~mm}$. Detection was done using densitometeric scanning at $254 \mathrm{~nm}$, $366 \mathrm{~nm}$ followed by derevatiztion with Fast blue salt B [3, 3' - dimethoxybiphenyl-4, 4'- bis (diazonium) - dichloride] and inspected in visible light. Flavonoids form blue or blue - violet (visible) azo dyes.

\section{DPPH assay}

The scavenging reaction between (DPPH•) and an antioxidant $(\mathrm{H}-\mathrm{A})$ can be written as:

$\mathrm{DPPH} \cdot+\mathrm{H}-\mathrm{A} \longrightarrow \mathrm{DPPH}-\mathrm{H}+\mathrm{A}$.

Antioxidants react with DPPH•, which is a stable free radical and is reduced to the DPPH-H and as consequence the absorbance decreased from the $\mathrm{DPPH} \cdot$ radical to the $\mathrm{DPPH}-\mathrm{H}$ form. The degree of discoloration indicates the scavenging potential of the antioxidant compounds or extracts in terms of hydrogen donating ability. DPPH radical scavenging activity from all plant extracts was measured by taking $100 \mu$ sample, $900 \mu \mathrm{l}$ of acetate buffer ( $\mathrm{pH} 6.5$ ) and $3 \mathrm{ml}$ freshly prepared $100 \mu \mathrm{M}$ DPPH solution in methanol. Reagent blank was $1 \mathrm{ml}$ buffer and $3 \mathrm{ml} \mathrm{DPPH}$ solution. The absorbance was measured after 90 min of incubation in dark at $517 \mathrm{~nm}$. DPPH 
radical scavenging activity (\%) was determined by following equation:

$\mathrm{DPPH}$ radical scavenging

Activity (\%) $=\mathrm{A}_{\mathrm{b}}-\mathrm{A}_{\mathrm{s}} / \mathrm{A}_{\mathrm{b}} \mathrm{X} 100$

Cell Viability test [MTT assay]

Goat liver was procured from the local slaughter house aseptically in $250 \mathrm{ml}$ sterile chilled phosphate buffered saline. It was chopped to fine pieces with the help of sterile scissors in vertical laminar air flow. The chopped pieces were incubated with equal amount of TPVG for $45 \mathrm{~min}$ in Orbitech rotary shaker at $370 \mathrm{C}$ at $105 \mathrm{rpm}$. $10 \%$ Serum was added to inhibit the action of trypsin after the completion of incubation. The cells were centrifuged at $3250 \mathrm{rpm}$ for $10 \mathrm{~min}$; the supernatant was subjected to Neubaur's Chamber for cell counting. Fifteen to twenty thousand cells were seeded in 96 well plates in $40 \mu$ l of PBS, incubated on rotary shaker for 2 hours at $370 \mathrm{C}$ at $95 \mathrm{rpm} .10 \mu \mathrm{l}, 20 \mu \mathrm{l}$ and $40 \mu \mathrm{l}$ of plant extract were added in each well followed by addition of $10 \mu \mathrm{l}$ MTT reagent [Yellow tetrzolium salt]. The plates were incubated in Orbitech rotary shaker at $370 \mathrm{C}$ at $100 \mathrm{rpm}$ for 4 hours. After the incubation $10 \mu$ l of lysis solution [20\% SDS in 50\% DMSO] was introduced in each well. The plates were further incubated at $370 \mathrm{C}$ at 100 rpm to solublize the puple coloration developed by conversion of tetrzolium salt. The O.D was recorded using Eliza reader at $492 \mathrm{~nm}$ and \% cell viability determined by:

$\%$ viability = Mean absorbance of sample X 100 Mean absorbance of control

\section{Intestinal absorption assay}

Goat intestine was procured from local slaughter house aseptically in $250 \mathrm{ml}$ sterile chilled phosphate buffered saline. The animal was starved 18 hours overnight to clear the upper intestine of faecal matter. The abdomen was opened and 1 meter intestine removed and transferred to chilled PBS. The first $15 \mathrm{~cm}$ of jejunum were discarded and next $25 \mathrm{~cm}$ of upper intestine were cut $5 \times 5 \mathrm{~cm}$. the lumen was flushed with Kreb's Hanslet buffer and everted. The everted intestine pieces were filled with PBS internally and sealed at both ends just as dialysis bags are sealed. Each of the sealed intestines was incubated at $370 \mathrm{C}$ in $100 \mathrm{ml}$ PBS containing

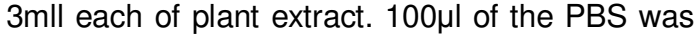
withdrawn at interval of $10 \mathrm{~min}$. and subjected to estimation of concentration by using Folin Ciocalteus method.

\section{Results and Discussions}

The graph of Quercitrin and absorbance at $765 \mathrm{~nm}$ was plotted and the total flavonoid content was detected form the standard graph as below:
Table 1-

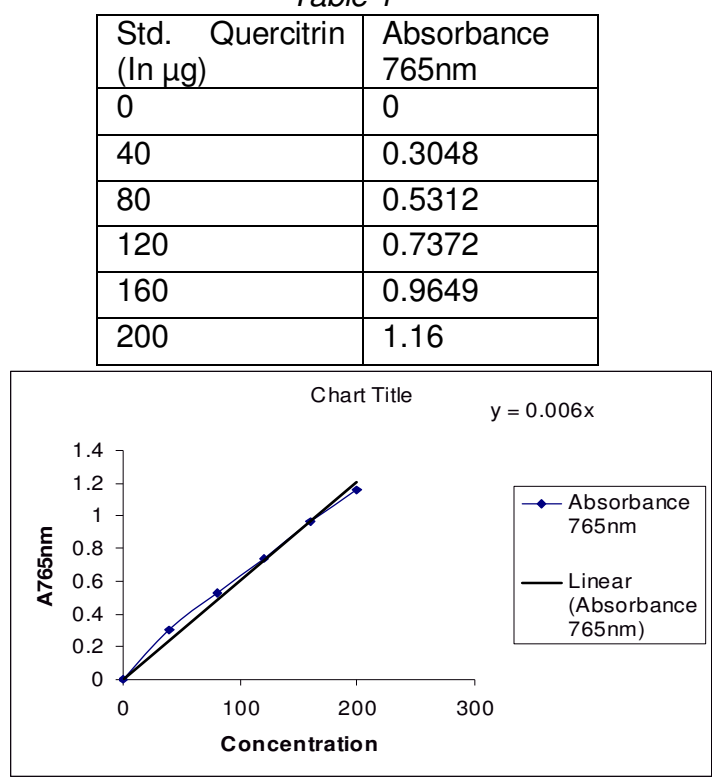

Fig. 1- The graph of Quercitrin and absorbance at $765 \mathrm{~nm}$ was plotted and the total flavonoid content

Table 2- Concentration of total flavonoids as detected by Folin - Ciocalteus method

\begin{tabular}{|l|l|l|l|}
\hline Name & A765nm & Conc. $\mu \mathrm{g} / 100 \mu \mathrm{l}$ & $\begin{array}{l}\text { Conc. } \\
\%\end{array}$ \\
\hline Acaica catechu & 4.88 & 813.33 & 0.8133 \\
\hline Emblica officinaes & 2.43 & 406.1 & 0.4061 \\
\hline Ficus benghalinsis & 3.44 & 574.21 & 0.5742 \\
\hline Ficus glomerata & 4.39 & 731.66 & 0.7316 \\
\hline Terminalia arjuna & 3.39 & 566.16 & 0.5661 \\
\hline
\end{tabular}

A. catechu showed the highest content of flavonoids and E.officinale the lowest. The concentration of flavonoids detected were E.officinalis < T.arjuna $<$ F.bengalensis < F.glomerata < A.catechu.

HPTLC analysis followed by scanning and derevatiztion confirmed the flavonoids and their $\mathrm{Rf}$ values the chemical nature of these flavonoids is yet to be identified.

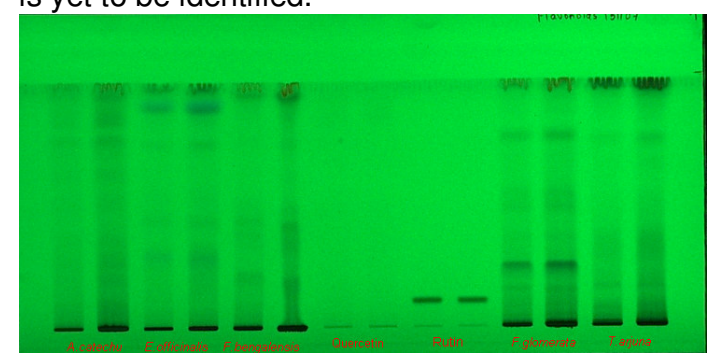

Fig. 2- Image @ 254 nm, Track 1 \& 2 - Acacia catechu, Track 3 \& 4 - Emblica officinalis, Track 5 \& 6 - Ficus benghalensis, Track 7 \& 8 Quercitrin, Track $9 \& 10$ - Rutin, Track 11 \& $12-$ Ficus glomerata, Track 13 \& 14 - Terminalia arjuna. 


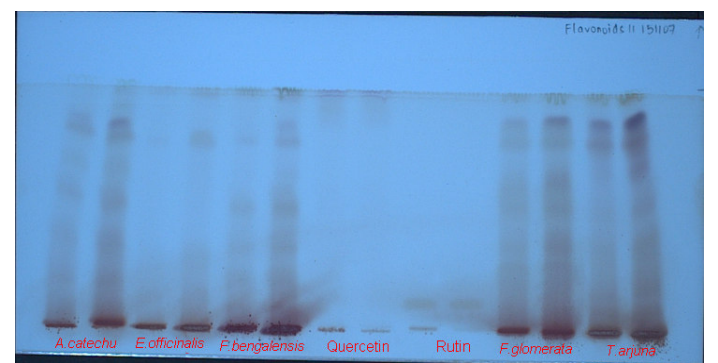

Fig. 3- Image @ visible light after Derivatisation: With Fast Blue B Salt, Track 1 \& 2 - Acacia catechu, Track 3 \& 4 - Emblica officinalis, Track 5 \& 6 - Ficus benghalensis, Track $7 \& 8$ - Quercitrin, Track 9 \& $10-$ Rutin, Track 11 \& 12 - Ficus glomerata, Track 13 \& 14

- Terminalia arjuna.

The flavonoids \& their Rf Values:

Table 3- Track 2: Acacia catechu

\begin{tabular}{cccccccccc} 
Peak & $\begin{array}{c}\text { Start } \\
\text { Rf }\end{array}$ & $\begin{array}{c}\text { Start } \\
\text { Height }\end{array}$ & $\begin{array}{c}\text { Max } \\
\text { Rf }\end{array}$ & $\begin{array}{c}\text { Max } \\
\text { Height }\end{array}$ & $\begin{array}{c}\text { Max } \\
\%\end{array}$ & $\begin{array}{c}\text { End } \\
\text { Rf }\end{array}$ & $\begin{array}{c}\text { End } \\
\text { Height }\end{array}$ & Area & \multicolumn{1}{c}{$\begin{array}{c}\text { Area } \\
\%\end{array}$} \\
\hline 1 & 0.07 & 0.7 & 0.11 & 11.7 & 2.56 & 0.12 & 0.1 & 275.2 & 1.76 \\
2 & 0.16 & 0.5 & 0.21 & 38.5 & 8.46 & 0.23 & 24.4 & 1257.8 & 8.04 \\
3 & 0.23 & 24.1 & 0.27 & 50.5 & 11.10 & 0.29 & 37.1 & 1543.4 & 9.86 \\
4 & 0.29 & 37.4 & 0.30 & 43.2 & 9.51 & 0.33 & 29.7 & 1145.2 & 7.32 \\
5 & 0.33 & 29.9 & 0.36 & 40.3 & 8.86 & 0.40 & 7.2 & 1520.2 & 9.72 \\
6 & 0.45 & 1.4 & 0.51 & 39.7 & 8.74 & 0.57 & 0.9 & 1667.0 & 10.65 \\
7 & 0.58 & 3.6 & 0.63 & 43.3 & 9.53 & 0.67 & 1.0 & 1430.9 & 9.15 \\
8 & 0.67 & 1.2 & 0.76 & 82.6 & 18.15 & 0.80 & 0.2 & 3298.9 & 21.08 \\
9 & 0.80 & 0.1 & 0.83 & 67.6 & 14.85 & 0.90 & 1.6 & 2846.9 & 18.20 \\
10 & 0.91 & 0.0 & 0.93 & 37.5 & 8.24 & 0.95 & 3.0 & 661.1 & 4.22
\end{tabular}

The flavonoids \& their Rf Values:

Table 4- Track 4: Emblica officinalis

\begin{tabular}{|c|c|c|c|c|c|c|c|c|c|}
\hline Peak & $\begin{array}{c}\text { Start } \\
\text { Rf }\end{array}$ & $\begin{array}{l}\text { Start } \\
\text { Height }\end{array}$ & $\begin{array}{c}\text { Max } \\
\text { Rf }\end{array}$ & $\begin{array}{l}\text { Max } \\
\text { Height }\end{array}$ & $\begin{array}{c}\operatorname{Max} \\
\%\end{array}$ & $\begin{array}{l}\text { End } \\
R^{\prime} f\end{array}$ & $\begin{array}{l}\text { End } \\
\text { Height }\end{array}$ & Area & $\begin{array}{c}\text { Area } \\
\%\end{array}$ \\
\hline 1 & 0.13 & 13.0 & 0.18 & 32.6 & 7.00 & 0.19 & 30.6 & 909.7 & 4.85 \\
\hline 2 & 0.19 & 32.1 & 0.28 & 100.7 & 21.62 & 0.37 & 3.2 & 6897.7 & 36.78 \\
\hline 3 & 0.38 & 1.7 & 0.43 & 41.5 & 8.91 & 0.48 & 1.3 & 1482.8 & 7.91 \\
\hline 4 & 0.51 & 4.6 & 0.53 & 10.9 & 2.35 & 0.57 & 3.5 & 332.7 & 1.77 \\
\hline 5 & 0.69 & 0.1 & 0.74 & 63.4 & 13.61 & 0.78 & 2.1 & 1739.0 & 9.27 \\
\hline 6 & 0.81 & 1.3. & 0.88 & 216.6 & 46.51 & 0.93 & 0.4 & 7393.1 & 39.42 \\
\hline
\end{tabular}

The flavonoids \& their Rf Values:

Table 5- Track 5: Ficus benghalensis

\begin{tabular}{cccccccccc} 
Peak & $\begin{array}{c}\text { Start } \\
\text { Rf }\end{array}$ & $\begin{array}{c}\text { Start } \\
\text { Height }\end{array}$ & $\begin{array}{c}\text { Max } \\
\text { Rf }\end{array}$ & $\begin{array}{c}\text { Max } \\
\text { Height }\end{array}$ & $\begin{array}{c}\text { Max } \\
\%\end{array}$ & $\begin{array}{c}\text { End } \\
\text { Rf }\end{array}$ & $\begin{array}{c}\text { End } \\
\text { Height }\end{array}$ & Area & $\begin{array}{c}\text { Area } \\
\%\end{array}$ \\
\hline 1 & 0.13 & 2.4 & 0.15 & 11.9 & 3.57 & 0.16 & 9.7 & 170.5 & 1.57 \\
2 & 0.16 & 9.4 & 0.21 & 64.4 & 19.35 & 0.25 & 2.1 & 2394.3 & 21.98 \\
3 & 0.29 & 0.0 & 0.38 & 59.9 & 17.99 & 0.41 & 44.3 & 2914.3 & 26.75 \\
4 & 0.41 & 44.6 & 0.43 & 63.4 & 19.03 & 0.47 & 27.4 & 2250.5 & 20.66 \\
5 & 0.47 & 27.6 & 0.50 & 37.5 & 11.25 & 0.55 & 2.6 & 1354.9 & 12.44 \\
6 & 0.72 & 1.5 & 0.76 & 23.2 & 6.97 & 0.79 & 1.1 & 664.5 & 6.10 \\
7 & 0.91 & 0.4 & 0.94 & 72.7 & 21.83 & 0.95 & 2.9 & 1146.0 & 10.52
\end{tabular}

The flavonoids \& their Rf Values:

Table 6- Track 11: Ficus glomerata

\begin{tabular}{cccccccccc}
\multicolumn{2}{c}{$\begin{array}{c}\text { Start } \\
\text { Peak }\end{array}$} & $\begin{array}{c}\text { Rftart } \\
\text { Hfight }\end{array}$ & $\begin{array}{c}\text { Max } \\
\text { Rf }\end{array}$ & $\begin{array}{c}\text { Max } \\
\text { Height }\end{array}$ & $\begin{array}{c}\text { Max } \\
\%\end{array}$ & $\begin{array}{c}\text { End } \\
\text { Rf }\end{array}$ & $\begin{array}{c}\text { End } \\
\text { Height }\end{array}$ & \multicolumn{1}{c}{ Area } & \multicolumn{1}{c}{$\begin{array}{c}\text { Area } \\
\%\end{array}$} \\
\hline 1 & 0.07 & 0.4 & 0.09 & 19.8 & 3.41 & 0.13 & 0.1 & 418.2 & 2.41 \\
2 & 0.13 & 0.2 & 0.16 & 39.7 & 6.86 & 0.18 & 0.3 & 643.9 & 3.71 \\
3 & 0.18 & 0.3 & 0.25 & 234.6 & 40.52 & 0.29 & 8.9 & 6857.8 & 39.46 \\
4 & 0.33 & 1.4 & 0.36 & 28.2 & 4.88 & 0.40 & 0.5 & 761.1 & 4.38 \\
5 & 0.44 & 1.0 & 0.49 & 64.3 & 11.11 & 0.51 & 52.5 & 2060.3 & 11.86 \\
6 & 0.52 & 53.9 & 0.53 & 62.2 & 10.74 & 0.61 & 1.5 & 2273.6 & 13.08 \\
7 & 0.72 & 2.5 & 0.77 & 130.1 & 22.48 & 0.83 & 0.8 & 4362.0 & 25.10
\end{tabular}

The flavonoids \& their Rf Values:

Table 7- Track 14: Terminalia arjuna

\begin{tabular}{cccccccccc} 
Peak & $\begin{array}{c}\text { Start } \\
\text { Rf }\end{array}$ & $\begin{array}{c}\text { Start } \\
\text { Height }\end{array}$ & $\begin{array}{c}\text { Max } \\
\text { Rf }\end{array}$ & $\begin{array}{c}\text { Max } \\
\text { Height }\end{array}$ & $\begin{array}{c}\text { Max } \% \\
\text { \% }\end{array}$ & $\begin{array}{c}\text { End } \\
\text { Rf }\end{array}$ & $\begin{array}{c}\text { End } \\
\text { Height }\end{array}$ & \multicolumn{1}{c}{ Area } & $\begin{array}{c}\text { Area } \\
\%\end{array}$ \\
\hline 1 & 0.07 & 0.3 & 0.09 & 21.1 & 7.45 & 0.12 & 0.1 & 351.6 & 2.92 \\
2 & 0.14 & 0.9 & 0.17 & 46.8 & 16.53 & 0.21 & 20.0 & 1350.4 & 11.20 \\
3 & 0.24 & 4.5 & 0.35 & 75.8 & 26.75 & 0.42 & 3.1 & 5697.6 & 47.24 \\
4 & 0.48 & 7.4 & 0.50 & 13.4 & 4.72 & 0.53 & 6.5 & 423.0 & 3.51 \\
5 & 0.63 & 7.3 & 0.66 & 19.5 & 6.89 & 0.69 & 0.2 & 628.5 & 5.21 \\
6 & 0.70 & 0.5 & 0.76 & 106.7 & 37.67 & 0.80 & 0.1 & 3609.9 & 29.93
\end{tabular}

Table 8- DPPH assay results showed the \% scavenging activities as

\begin{tabular}{|l|l|}
\hline Name & scavenging \\
\hline & activity \\
\hline Acacia catechu & \\
\hline Emblica officinalis & $0.83 \mu \mathrm{gg}$ \\
\hline Ficus benghalensis & $0.90 \mu \mathrm{g}$ \\
\hline Ficus glomerata & $0.85 \mu \mathrm{g}$ \\
\hline Terminalia arjuna & $0.87 \mu \mathrm{g}$ \\
\hline
\end{tabular}

Lower the scavenging activity higher is the antioxidant potential. The values above indicate the antioxidants of the plant can be considered as best Nutraceutical and hold a good prospective for further investigation as chemotherapeutic agents.

Table 9- MTT assay gave the following results:

\begin{tabular}{|l|l|l|}
\hline Name & $\begin{array}{l}\text { O.D of } \\
\text { control }\end{array}$ & O.D of \\
\hline & & sample \\
\hline Acacia catechu & 0.063 & 0.065 \\
\hline Emblica officinalis & 0.047 & 0.048 \\
\hline Ficus benghalensis & 0.016 & 0.016 \\
\hline Ficus glomerata & 0.008 & 0.008 \\
\hline Terminalia arjuna & 0.131 & 0.131 \\
\hline
\end{tabular}

The cell viability count at $40 \mu \mathrm{l}$ sample [maximum] was $96 \%, 97 \%, 100 \%, 100 \%$ and $100 \%$ for Acacia catechu, Emblica officinalis, Ficus benghalensis, Ficus glomerata, Terminalia arjuna respectively. Intestinal absorption assay revealed that the compounds are easily assimilated from the intestinal lumen. The uptake of these compounds for $30 \mathrm{~min}$ was recorded as below

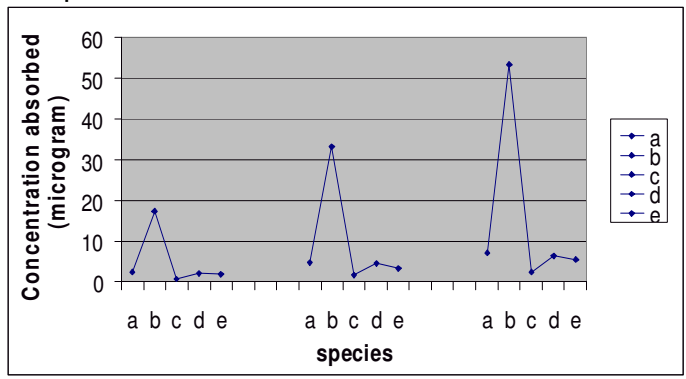

Fig. 3- Graph representing Intestinal absorption at 10,20,30 min. a, b, c, d, e are Acacia catechu, Emblica officinalis, Ficus benghalensis, Ficus glomerata \& Terminalia arjuna respectively. There after absorption was constant. 
Table 10a,b,c,- Intestinal absorption values as determined by Folin - Ceocalteus Method:

At $10 \mathrm{~min}$

\begin{tabular}{|l|l|l|l|}
\hline Name & & $\begin{array}{l}\text { A765nm } \\
(10 \mathrm{~min})\end{array}$ & $\begin{array}{l}\text { Concentration } \\
(10 \mathrm{~min})\end{array}$ \\
\hline Acaica catechu & $\mathrm{a}$ & 0.0144 & 2.4 \\
\hline Emblica officinaes & $\mathrm{b}$ & 0.1045 & 17.42 \\
\hline Ficus benghalinsis & $\mathrm{c}$ & 0.0048 & 0.8 \\
\hline Ficus glomerata & $\mathrm{d}$ & 0.0129 & 2.15 \\
\hline Terminalia arjuna & $\mathrm{e}$ & 0.0108 & 1.8 \\
\hline
\end{tabular}

At $20 \mathrm{~min}$

\begin{tabular}{|l|l|l|l|}
\hline Name & & $\begin{array}{l}\text { A765nm } \\
(20 \mathrm{~min})\end{array}$ & $\begin{array}{l}\text { Concentration } \\
(20 \mathrm{~min})\end{array}$ \\
\hline Acaica catechu & $\mathrm{a}$ & 0.0289 & 4.82 \\
\hline Emblica officinaes & $\mathrm{b}$ & 0.2 & 33.33 \\
\hline Ficus benghalinsis & $\mathrm{c}$ & 0.01 & 1.67 \\
\hline Ficus glomerata & $\mathrm{d}$ & 0.027 & 4.5 \\
\hline Terminalia arjuna & $\mathrm{e}$ & 0.02 & 3.33 \\
\hline
\end{tabular}

At $30 \mathrm{~min}$

\begin{tabular}{|l|l|l|l|}
\hline Name & & $\begin{array}{l}\text { A765nm } \\
(20 \mathrm{~min})\end{array}$ & $\begin{array}{l}\text { Concentration } \\
(20 \mathrm{~min})\end{array}$ \\
\hline Acaica catechu & $\mathrm{a}$ & 0.0432 & 7.2 \\
\hline Emblica officinaes & $\mathrm{b}$ & 0.32 & 53.33 \\
\hline Ficus benghalinsis & $\mathrm{c}$ & 0.0144 & 2.4 \\
\hline Ficus glomerata & $\mathrm{d}$ & 0.0389 & 6.48 \\
\hline Terminalia arjuna & $\mathrm{e}$ & 0.0324 & 5.4 \\
\hline
\end{tabular}

\section{Conclusion}

From the above results \& discussion it can be concluded that the above mentioned plants not only contain good quantity of flavonoids but also these flavonoids hold a good prospective as Nutraceutical \& chemotherapeutics agents because of their antioxidant potential, no cytotoxicity \& good Intestinal absorption

\section{Acknowledgment}

The current work is funded by 'BCUD', University of Pune; carried out at 'VidyaPrathisthan School of Biotechnology', Baramati. I extend my thanks to 'Indian Red Cross Society' Baramati for allowing me to use Eliza reader. I am thankful to Dr. MS Patole Sir, 'Scientist E' at NCCS, Pune. The work is dedicated to all my teachers and students.

\section{References}

[1] Miller H.E., Rigelhof F., Marquart L., Prakash A. and Kanter, M. (2000) Cereal Foods World 45(2), 59-63.

[2] Miller H.E., Rigelhof F., Marquart L., Prakash A. and Kanter M. (2000) J. Am. Coll. Nutr. 19(3), 312S-319S.

[3] Prior R.L., Cao G., Martin A., Sofi c, E., McEwen J., O'Brien C., Lischner N., Ehlenfeldt M., Kalt W.,Krewer G., \&
Mainland C.M. (1998) J. Agric. Food Chem. 46, 2686-2693.

[4] Cao G., Verdon C.P., Wu A.H.B., Wang H., \& Prior R.L. (1995) Clin, Chem., 41, 1738-1744.

[5] Vinson J.A., Hao Y., Su X., \& Zubik L. (1998) J.Agri. Food Chem. 46, 36303634.

[6] Cuvelier M. E., Richard H., \& Berset C. (1992) Biosci. Biotech. Biochem. 56, 324-325.

[7] Hogg J. S., Lohmann D. H. \& Russell K. E. (1961) Can. J. Chem. 39, 1588-1594.

[8] Cao G., Sofi c, E. \& Prior R. L. (1966) J. Agric. Food Chem. 44, 3426-3431.

[9] Wang H., Cao G. \& Prior R.L. (1996) J. Agric. Food Chem. 44, 701-705.

[10] Taylor S. E., Edwards M., Williamson E., Evans F. J. (1981) J. Pharm. Pharmacol. 33, 54.

[11] Hildebert Wagner, Sabine Bladt. (1996) Plant Drug Analysis, Springer publication, 195 -197.

[12] Glavind J. and Holmer G. (1967) J. Am. Oil Chem. Soc. 44: 539-542.

[13] Heinonen I.M. et al. (1997) J. Agric. Food Chem. 46:25-31.

[14] Hopia A.I. et al. (1996) J. Agric. Food Chem. 44:2030-2036.

[15] Namiki M. (1990) Crit. Rev. Food Sci. Nutr. 29: 273--300.

[16] Howell J.C. (1986) Food and Chemical Toxicology. 24: 997-1002.

[17] Kurechi T. et al. (1980) Chem. Pharm. Bull. 2089-2093.

[18] Blair T.A., Johnson I.T. (1974) Jour. Of physiology. 236 (3), $653-661$.

[19] Lubica Lacikova et. Al. Antioxidant activity of total phenols in different extracts of four Staphylea. L. species. Molecules. ISSN: 1420 - 3049. http://www.mdpi.org 